\title{
THE PECKHAM HEALTH CENTRE, "PEP”, AND THE CONCEPT OF GENERAL PRACTICE DURING THE 1930s AND 1940s
}

\author{
by
}

\author{
JANE LEWIS AND BARBARA BROOKES*
}

\begin{abstract}
THIS paper documents the proposals put forward by George Scott Williamson and Innes Pearse, founders of the Peckham Health Centre and members of the Political and Economic Planning (PEP) Health Group, to enhance the role and status of the general practitioner (GP). Their ideas are significant in terms of their understanding of the threat that specialism posed to general practice and of the problems of control and finance raised by reform. Their solution - the establishment of GP therapeutic centres or cells - is located in terms of their own ideas regarding health and medical practice and is compared with the other major proposal for group practice in health centres, which emanated from the Dawson Committee in 1920. Finally, the paper provides some suggestions as to the reason for their failure.
\end{abstract}

\section{INTRODUCTION}

The Peckham Health Centre was opened in 1926 in a small house in Queen's Road, Peckham, London SE15, by George Scott Williamson and Innes Pearse, who were both qualified medical practitioners. The first Centre closed in 1930, and Williamson and Pearse spent five years raising the money for a new building, which opened on St Mary's Road, Peckham, in 1935 and which continued to operate, with the exception of the war years, until 1950. At the time, the Centre drew considerable comment. Its published reports were noticed in all the major medical journals and during the last eighteen months of its existence it attracted some 12,000 visitors. Today, the Peckham Centre is remembered chiefly for the way in which it managed to involve the local community in the delivery of primary health care, for the emphasis it placed on "positive health", and for its progressive attitudes towards the management of pregnancy and infant care. ${ }^{1}$

Less well-known is the place the Centre occupied in Williamson and Pearse's wider vision of the health services. The Peckham Centre was but one part of a comprehen-

\footnotetext{
*Jane Lewis, PhD, Department of Social Science and Administration, London School of Economics and Political Science, London WC2A 2AE; and Barbara Brookes, Department of History, Bryn Mawr.

${ }^{1}$ Brian Abel-Smith, 'Towards a healthier population', New Society, 15 October 1981, p. 97; John Ashton, 'The Peckham experiment', Community Health, 1977, 8: 132-137.
} 


\section{Jane Lewis and Barbara Brookes}

sive plan to reform medical practice and health care delivery. The Centre itself was based on the premiss that the promotion of health must be completely separated from the prevention and cure of disease. Williamson and Pearse regarded it as an experimental human research laboratory designed to test their idea that the social situation of the family was the main source of either healthy growth and development, or disease and social disintegration. Only families were permitted to join, each paying a weekly subscription of one shilling pre- and two shillings post-war, a not inconsiderable sum when club subscriptions for health purposes usually amounted to only $1 d$ or $2 d$ per week. All members of the Centre agreed to submit to periodic "health overhauls" designed to check their capacity for individual, family, and social life. The Centre also provided extensive recreational facilities (including a swimming-pool, gymnasium, roller-skating rink, and billiards-tables), the idea being that in using them members would enrich their family lives and further their own personal development. Peckham was chosen as the site for the Centre because it was a reasonably prosperous community where families might be expected to improve in health with the sole addition of the kind of facilities and services the Centre provided.

There was thus very little connexion between the ideas behind the Peckham Centre and either the plans for health centres drawn up by the Dawson Committee after World War I or the experimental health centres opened during the inter-war period. ${ }^{2}$ Innes Pearse referred to the latter derisively as "polyclinics" because they grouped "sickness services", such as venereal diseases and tuberculosis clinics together with what should have been "health" services, such as maternal and child welfare clinics. ${ }^{3}$ What Williamson and Pearse wanted to see was a new health service modelled on the work of the Peckham Centre and a restructured and reformed medical service which would enlarge the role and enhance the status of the GP. Their plans for the medical services centred on what Williamson called GP therapeutic centres or cells and it was these, rather than the Peckham Centre, which approximated to the proposals for health centres contained in the Dawson Report. Williamson and Pearse's ideas regarding the separation of health and medical services, and the restructuring of general practice are dealt with in the sections which follow. They were concerned above all to strengthen general practice in face of the threat posed by increasing specialization. They were also determined that any reform of general practice should not threaten the autonomy of the individual practitioner.

Apart from their own prolific writings, the main forum for Williamson and Pearse's ideas throughout the 1930s was the PEP Health Group, which Williamson chaired and which was responsible for the PEP Report on the British Health Services published in 1937. Williamson and Pearse's efforts to think about the meaning of health during the 1930s represented one of the few attempts to carry the discussion of health care beyond the reform of the existing system, although few of their contemporaries understood or accepted their attempt to distinguish between health and

2 Parliamentary Papers (PP), 'Report of the Consultative Council on Medical and Allied Services', 1920, Cmd. 693, XVII, 1001.

${ }^{3}$ I. Pearse and L. Crocker, The Peckham experiment. A study in the living structure of society, London, Allen \& Unwin, 1943, p. 49. 


\section{The Peckham Health Centre}

medical practice and between health centres and therapeutic centres or cells. Thus the Peckham Health Centre tended to be reviewed in terms of its contribution to established medical practice rather than as the qualitatively different enterprise Williamson and Pearse intended it to be. And while health centres for what Williamson and Pearse would have termed medical practice eventually came into being in large numbers after 1966, they took a very different form and played a less important role than that envisaged for them by the founders of the Peckham Centre.

\section{THE PROPOSED DIVISION OF LABOUR BETWEEN HEALTH AND MEDICAL PRACTICE}

Their colleagues on the PEP Health Group had difficulty coming to terms with Williamson and Pearse's belief in the necessity for a complete break between health and medical services, pointing out that the GP acted as an adviser to the family on all matters to do with health as well as sickness. But Williamson insisted that the GP could not be responsible for maintaining the health of his patients because his professional ethics forbade him from visiting his patients until they asked him to. The first survey of 500 families who were members of the Peckham Centre revealed that fifty-nine per cent of individuals suffered from ailments despite believing themselves to be well, and a second survey of a random 500 families showed a ten per cent increase in this figure. ${ }^{4}$ Williamson and Pearse argued that because the GP stood little chance of diagnosing these disorders, he should content himself with the position of "therapeutic agent" for which the exigencies of both his practice and his training suited him.s

Williamson stressed that medical practice and health practice had different roots. Medicine derived from the science of pathology, which he defined as the study and knowledge of suffering. Williamson and Pearse complained that GPs received no training in the functioning of the healthy body, and Pearse maintained that she had had to start infant welfare work in the East End of London after World War I without ever having seen a healthy baby. ${ }^{6}$ According to Williamson, the pathologist/doctor's job was to teach people to compensate for their diseases or disorders and then to return them to society. His measure of fitness was determined by the individual's capacity to function in his everyday life and the need to protect society from infection. It was, in other words, a social standard and one he had to persuade the patient to accept. The practice of health, on the other hand, derived from biology rather than pathology. Williamson illustrated the difference between the standard of health expected by the health practitioner by reference to the reports of medical officers of health, which measured children's health in terms of the number of tonsillectomies performed or spectacles prescribed. These were pathological measures of health. The health practitioner would only be satisfied when the reports showed that neither tonsils nor eyesight were defective. ${ }^{7}$ Such a concept was arguably utopian, and Williamson

4 Ibid., pp. 13-23.

s PEP papers, WG 15/2, Minutes of meeting of PEP Health Group, 16 December 1936.

-I. Pearse, interview, 1979.

' PEP Papers, WG 15/1, 'An inquiry into the state of medical practice. Document summarising the views of Dr Williamson of the Pioneer Health Centre', 27 May 1935. 


\section{Jane Lewis and Barbara Brookes}

was criticized for proposing an absolute standard of physical health which denied that people could be useful or happy with minor disorders such as bunions or poor teeth. As Pearse admitted, the application of the Peckham Health Centre standard of health on a countrywide scale would have flooded the medical services with people needing treatment.9 On the other hand, Williamson and Pearse argued that the general standard of health was only so poor because of the exclusively medical approach to health care. The answer was thus to establish first a network of "genuine" health centres on Peckham lines throughout the country, and second, an efficient network of medical centres concentrating solely on the treatment of disease. The GP would be confined to the latter and would cease to have anything to do with the cultivation and maintenance of health, such as giving advice on diet, antenatal work, or infant care.

Williamson and Pearse contrasted their health practice at the Centre with the work of an infant welfare clinic:

It is not a clinic for the sick, for its doctors, with some justification, are not permitted to treat the infant if sick, but must refer it to a clinician. Nor is it a 'health organization' for it has no instruments for the cultivation of health, and is content to work under the disability of dealing with the infant as an entity dissociated from the natural mechanism of nurture - the family.10

Pearse had been dismayed by the "lack of rationality" in the work of the infant welfare clinic she had practised in during the early 1920s. In contrast to the Peckham Centre, the clinic lacked constant contact with the mother, the doctor did not live in the neighbourhood, and mothers tended to use it only in emergencies. Nor was there ever enough time to examine the mother thoroughly to establish why, for example, her milk was failing. ${ }^{11}$

Williamson and Pearse believed that the key to health lay in the relationship between the whole human being, or organism, and the environment, and that it was the job of the health practitioner to promote healthy interaction between the two. They contended that the physician made the mistake of the pathologist and treated the parts of the body in isolation. In arguing this they followed the ideas of Sir James Mackenzie, whom they met at the London Hospital. In 1919, Mackenzie published a "critical" and "constructive" account of contemporary health practice, entitled The future of medicine, in which he explained the necessity of studying the whole individual in order to detect the early stages of disease. ${ }^{12}$ In his own research on the heart, Mackenzie stressed the importance of relating the functions of the heart to the functions of the body as a whole. Like Mackenzie, Williamson believed that of all medical practitioners the GP came closest to an understanding of the whole person, chiefly because of his knowledge of the home environment and habits of the individual patient. It was this belief which led Williamson to champion the cause of the GP

\footnotetext{
'H. I. Winner, 'The end of the Peckham experiment', Scientific Worker, July 1950, 5: 18-20.

- Pearse to C. P. Blacker, 10 June 1944. Eugenics Collection, Contemporary Medical Archives Centre, Wellcome Institute for the History of Medicine.

10 Pearse and Crocker, op. cit., note 3 above, p. 281.

"I. Pearse, 'The Peckham Health Centre', Medical Women's Quarterly, January 1936. Reprint in Eugenics Collection, Contemporary Medical Archives Centre, Wellcome Institute for the History of Medicine.

12 James Mackenzie, The future of medicine, London, Oxford University Press, 1919.
} 
against the specialist and to advocate a restructuring of the medical services which would enhance the role and status of the GP.13

\section{THE NEW GENERAL PRACTICE}

Williamson based his claim for the GP on the latter's role as a diagnostician. He argued that only the GP possessed sufficient information about a patient to make an accurate diagnosis and that he should therefore be given the central place in any medical service. The first step was to provide the GP with appropriate facilities. Williamson deplored the decline in family practice, which he blamed on the panel system (started under the 1911 National Health Insurance Act), and more broadly, on urbanization, which had segregated the social classes and led to the growing number of lock-up surgeries in the working-class districts. He described the situation thus:

There is in fact no social contact between the modern doctor and the homes of his patients (where they have homes). The basis of practice today is consultative .... Family practice is dead; that is why we cry out for psychology specialists to deal with situations that were naturally dealt with 60 years ago by the family doctor .... It is already dead and should indeed be properly cremated and not left to moulder and decay in lock-up surgeries and in the miserable homes of poor doctors driven to practise and live in poor areas, where their children and wives are exposed to social isolation. ${ }^{14}$

He did not suggest that the general practitioner should try to resuscitate the family doctor system, which would only be wasteful; rather he envisaged the GP continuing to work as a family doctor but replacing the system of house-calls and surgery hours by a consultative practice based on a well-equipped group practice centre: the therapeutic centre or cell. Williamson admitted that the standards of general practice in Peckham were generally not high. ${ }^{15}$ Certainly many of the former members of the Centre interviewed for this study confirmed that they had virtually ceased going to their family doctors, preferring to rely on the Centre instead. But Williamson and Pearse were careful not to lay the blame for this situation at the door of the GP, insisting that better working conditions would improve the standards of practice.

The most obvious way to provide GPs with the facilities they needed to improve their efficiency and their status was to pool resources. Williamson proposed to the PEP Health Group that about six GPs should join together in a therapeutic centre which would provide them with access to technical assistance, radiographic and laboratory facilities. The cells would also facilitate greater communication among doctors and between doctors and specialists. Each cell would serve a radius of twentyfive or even fifty miles and would consist of a cluster of consulting rooms around a mass consulting theatre furnished with apparatus for diagnosis and treatment. The GPs would be responsible for keeping careful records. All cases needing a second opinion would first be referred to a daily mass consultation of all the GPs working in the cell. Only then would the patient be referred to a specialist. Williamson's idea was thus to "slowly but surely reduce specialism to the necessary minimum". Every

${ }^{13}$ PEP Papers, WG 15/2, 16 December 1936.

14 PEP Papers, WG 15/1, 27 May 1935.

1s Peckham Archives, Tunbridge Wells, Minutes of the Peckham Health Centre Executive, 24 April 1947. 
graduate would spend a year as a resident officer to a cell before joining it; thus medical education would provide formal recognition of the new status of the GP. The cell would also take over the diagnostic work and treatment provided by the poor law and school medical services. The new system would operate for the convenience of the patient with an appointments system and the provision of cheap transportation to each cell. ${ }^{16}$

By 1945, Williamson had further elaborated these ideas. The cells were then to contain between ten and twelve doctors, working individually to ensure professional freedom, although still coming together for mass consultations. GPs would also control access to hospital beds. Williamson envisaged additional treatment centres in factories and advocated that treatment be medically supervised at all times. ${ }^{17}$ Indeed, Williamson drew a firm line between expert and layman in both his plans for the medical service and at the Peckham Health Centre, where member families had no voice in the direction of the Centre.

THE WILLIAMSON THERAPEUTIC CELL COMPARED WITH THE DAWSON HEALTH CENTRE

There were many similarities between Williamson's ideas for reforming medical practice and those expressed in the 1920 Report of the Consultative Council on Medical and Allied Services chaired by Lord Dawson, which advocated the setting-up of health centres similar in many respects to Williamson's proposed GP cells. The Report was initially welcomed by The Times because the medical correspondent, McNair Wilson, admired the work of Sir James Mackenzie, whose work had so greatly influenced Williamson. Mackenzie had left the London Hospital to set up a Research Institute at St Andrews in 1919, where GPs investigated the onset of disease. The Institute was very much an expression of Mackenzie's faith in the ability of the GP to involve himself in basic research through careful observation of his patients and record keeping. It seemed to McNair Wilson, as it did to Williamson, that some form of group practice would allow Mackenzie's example to be emulated. ${ }^{18}$

The Dawson Report envisaged two types of health centre. Primary health centres would provide GPs with operating rooms, beds, radiography, laboratory and dispensing facilities, and massage and physical culture services. (In Williamson's scheme, the latter fell within the ambit of the health rather than the medical service.) Secondary health centres would be staffed by consultants and offer specialist services. The Report claimed that the primary centres would enhance the GP's role as diagnostician and bring his isolation to an end. However, Dawson wished to extend the role of the GP into both preventive and curative medicine, which he believed could not be separated on any sound principle. In fact, Dawson's main aim was to enable the GP to reclaim from the medical officer of health and the local authority maternal and child welfare and other "preventive" work, which in Williamson's formulation would not be dealt with in therapeutic cells. Dawson was also less concerned than Williamson about

16 PEP Papers, WG 15/1, 27 May 1935, pp. 10-13.

17 G. S. Williamson, Physician heal thyself, London, Faber, 1945, pp. 24-51.

${ }^{18}$ Frank Honigsbaum, The division in British medicine, London, Kogan Page, 1979, p. 99. 


\section{The Peckham Health Centre}

the threat posed by specialism to general practice. Thus, while GPs would control the beds in primary centres, the Report stated firmly that patients in the secondary centres would be the responsibility of the consultants. Williamson proposed to give the GP control over all access to hospital beds. ${ }^{19}$

The Dawson Report was criticized by state medical officers for the way in which it ignored the important contribution made by the public health services. ${ }^{20}$ Williamson agreed with Dawson that preventive and curative medicine were essentially one, but because he drew such a firm line between medical and health services he could not permit the GP to intrude on any aspect of health practice. Thus, for example, the Peckham Health Centre covered all aspects of maternal and child welfare work. The PEP Health Group decided that until a health service on Peckham lines was implemented, the solution was to allow local authority services in this area to continue.

\section{ISSUES OF CONTROL AND FINANCE}

The Dawson Report saw health centres as a means of reorganizing clinical practice while avoiding any change to a salaried service, but it remained vague as to who was to control the centres, refusing to recommend either control by the local authority or an independent body. Williamson's ideas on control were firm. He pleaded passionately for a self-governing profession, as free as possible from external administrative interference. He argued to the PEP Health Group that medicine was an art as well as a science and would be killed if restricted by outside interference. The Group found it difficult to reconcile this view with the need to supervise the expenditure of public funds and with the desirability of exercising some general administrative control over all the health and medical services of the community. ${ }^{21}$ Williamson had no answer to the latter point, but in response to the former he proposed lay committees of subscribers to run both the cells and the district hospitals. He argued that these should be composed of parents only, because all social services were essentially domestic (Williamson and Pearse also believed that only parents had achieved full biological maturity). The members of the lay committees would contribute financially according to their means and the subscriptions would be held in safe-keeping by the treasury. The committees would be responsible only for the maintenance of the cells; patients would pay the doctors directly, again, according to means. ${ }^{22}$ The major aim here was to avoid both state control and any move towards a salaried service.

The British Medical Association (BMA) was also suspicious of control by local authorities, fearing that it would lead to a full-time salaried service. These linked issues became central in the debate over health centres (or GP cells in Williamson's terminology) during the 1940s. The BMA's Medical Planning Commission of 1942 accepted the idea of health centres but not municipal control. ${ }^{23}$ On the other hand, the Socialist Medical Association (SMA) favoured the idea of local authority control, as

19 PP, op. cit., note 2 above, paras. 6 and 61 .

${ }^{20}$ Arthur Newsholme, Medicine and the state, London, Allen \& Unwin, 1932, p. 104; J. M. Mackintosh, Trends of opinion about public health, Oxford University Press, 1943, p. 86.

${ }^{21}$ PEP Papers, WG 15/1, 1 May 1936.

22 Williamson, op. cit., note 17 above, pp. 60-70.

${ }^{23}$ BMA, 'Draft interim report of the Medical Planning Commission', Br. med.J., 1942, i: 743-753. 


\section{Jane Lewis and Barbara Brookes}

did the Ministry of Health officials. ${ }^{24}$ The problem of administration continued to dog the whole question of health centres after 1946; the famous Woodberry Down Centre, built at a cost of $£ 180,000$ by the London County Council, remained empty for a year after its opening in 1952 because local doctors feared losing their practices if they moved into it.

While Williamson's principles were a source of strength in terms of the clarity of his objectives, their radical nature tended to leave him outside the mainstream of contemporary debate. For example, his distrust of state control was not a matter of professional self-interest and therefore subject to negotiation, but rather a matter of principle. First, Williamson condemned the state panel service as an inefficient "sickness service" (he had organized opposition to national health insurance in Bristol when the Bill was passed in 1911). Second, the state saw no place for the kind of health service Williamson envisaged. (He regarded the closure of the Peckham Health Centre in 1950 as "a victory for state pathology". ${ }^{25}$ ) Finally, any free service provided by the state posed a threat to the concept of responsibility that Williamson considered crucial for the cultivation of health. He believed that "health demands that a man shoulder his own burden. It is better that he receive his whole wage and himself take the responsibility for his own welfare than that he be given what is perceived to be good for him and robbed of responsibility. The one spells health, the other atrophy and degeneration"; ${ }^{26}$ hence his insistence that members of the Peckham Health Centre pay a weekly subscription. Williamson maintained that the Peckham members were only too happy to spend their spare cash on something worthwhile rather than on visits to the dance hall or the pub. In fact, out of 720 family memberships in 1947 (the number fell far short of the target of 2,000 families), only 580 were making regular payments. ${ }^{27}$

Williamson was not opposed to the idea of one optimum standard of medical service for all in the form of a national health service, he objected only to the means of administering it. In his proposals for both a health and a sickness service, Williamson was concerned to preserve direct contact between the individual and the medical practitioner through devices such as the lay committees and through an improved patient/doctor relationship. In meetings of the PEP Health Group, Pearse strongly expressed her desire to see the patient/doctor relationship in the GP cells resemble that between the "biologists", as Williamson and Pearse liked to call themselves, and family members at the Peckham Health Centre. ${ }^{28}$ Thus far the grounds for Williamson's opposition to state intervention were unexceptional, but when he also demanded that in the case of both health and medical services the individual must take responsibility for his own health by paying his way, he greatly distanced himself from current opinion and in particular from the SMA, which was the chief source of support for the kind of GP cells he had in mind. The SMA advocated municipally con-

\footnotetext{
24 Honigsbaum, op. cit., note 18 above, pp. 185-213.

${ }^{25}$ GLC Archives, PH/PHS/1/7, Medical Officer, 20 December 1950.

${ }^{26}$ I. Pearse and G. S. Williamson, The case for action, London, Faber, 1931, p. 130.

${ }^{27}$ Peckham Archives, Minutes of the PHC Executive, 21 January 1947.

2s PEP Papers, WG 15/2, 16 December 1936.
} 


\section{The Peckham Health Centre}

trolled health centres staffed by salaried GPs as a means of redistributing medical care. $^{29}$

Both the Dawson plan for health centres and Williamson's scheme for GP cells had the virtue of laying out clearly what facilities and services would be provided. They did so out of a desire to promote the interests of the GP, but Williamson's scheme was further sharpened by his notion of the difference between health and medical practice and by his ideas as to the general principles governing the cultivation and maintenance of health. Health centres were not established in large numbers as recommended by the Dawson Report, in part because of the economy cuts of the early 1920s. A few centres were opened between 1920 and 1946, but apart from Peckham, whose title of "Health Centre" was misleading, these lacked any coherent philosophy as to what services and facilities should be provided, by whom, and under whose control. For example, the Finsbury Centre, with its tuberculosis clinic, public health laboratory, cleansing and disinfection station, mortuary, and offices for health visitors and sanitary inspectors represented an ad hoc collection of local authority services housed under one roof: ${ }^{30}$ the archetypal polyclinic so despised by Williamson and Pearse. During the early 1940s, the health centre was seen as the vital link connecting the tripartite structure of the proposed National Health Service (NHS), but once again its role remained vague. Section 21 of the 1946 NHS Act allowed health centres to provide for GP, dental, pharmaceutical, specialist and outpatient services, local authority clinics, and health education, but in what proportion and to what end was not clear. The health centres of the 1960s bore little relation to Williamson's design for GP cells in terms of either their more limited facilities, their administration, or the low level of co-operation between GPs using them.

\section{THE FAILURE OF WILLIAMSON'S IDEAS}

Even the PEP Report on the health services made little reference to Williamson's central idea of separate health and medical services apart from a paragraph acknowledging the "strong representation" that had been made as to the impossibility of the GP also doing "constructive health work". Reference to the Peckham Health Centre was included only under the heading of "health education". However, the report did accurately reflect the importance Williamson and Pearse attached to the GP as a "specialist in diagnosis" and recommended the establishment of what it called "central dispensaries" on the lines first called for in the Dawson Report. ${ }^{31}$

Williamson's failure to influence the medical profession was due in part to his own personality and in part to the profession's refusal to accept his idea of the distinction between health and medical practice. In an internal, unsigned memorandum on the work of the PEP Health Group, the flaws in the Report and in particular its lack of focus, were explained in terms of the Group's failure "to appreciate the complex administrative economic problems involved in the health service". This in turn was attributed to the poor chairmanship provided by Williamson:

29 'Whither medicine?', Medicine Today and Tomorrow, 1939, 2: 3-18.

${ }^{30}$ A. B. Stewart, 'Health centres of today', Lancet, 1946, i: 392.

${ }^{31}$ Report on the British health services, London, PEP, 1937, pp. 161-164. 
Dr Scott Williamson is an idealist possessed of a missionary spirit, while the inquiry and the Report were greatly assisted by his clear conceptions of the needs of a reorientated health service he was not a suitable person to guide a factual and important inquiry over the whole range of these services. ${ }^{32}$

Other observers also remarked on the arbitary methods used by Williamson. Frances Donaldson (whose husband, Jack Donaldson, gave $£ 10,000$ to help build the New Centre opened in 1935) went so far as to call him a "dictator". ${ }^{33}$

It is also true that Williamson and Pearse failed to demonstrate that health practice could be differentiated from medical treatment. The "health overhaul" employed at the Peckham Centre was, after all, essentially a medical examination. Moreover, Williamson and Pearse could produce no quantifiable data in support of their most important assertion: that the Peckham Health Centre had witnessed orderly growth and healthy development in family life. Observers were impressed most by the large amount of undiagnosed illness the Peckham Health Centre discovered and the only issue relating to Williamson and Pearse's concept of health that emerged for discussion was whether the cost of regular periodic overhaul for the whole population could be justified in terms of preventive medicine.

Members of the medical profession tended to regard the wide variety of issues that the Peckham investigators considered crucial to health practice as irrelevant. For example, Williamson and Pearse devoted a large amount of their time to publicizing the importance of whole foods and became involved in a dubiously scientific venture, called the Living Soil Society, founded by Lady Evelyn Balfour. ${ }^{34}$ The Society considered the most pressing problem facing the post-war world to be that of soil erosion. To Williamson and Pearse, this aspect of their work was as important as any other, but to medical observers it appeared merely unfortunate that their concern with "social causes" diverted them from the really important work of health overhauls. ${ }^{35}$

The medical profession came closest to an appreciation of Williamson's notion of health, if not to the need to separate health and medical practice, during the early 1940s, when it gave a general expression of support to the need for the planned NHS to encourage some form of "positive health". John Ryle, who took the first chair of Social Medicine at Oxford in 1943, wrote to Williamson that he had tried for many years "to think of medicine as 'the biology of Man in health and disease" ". ${ }^{36}$ However, he still believed, unlike Williamson, that good social medicine had to be grounded in sound social pathology. ${ }^{37}$ The BMA's Medical Planning Commission stressed that any reform of the medical services should ensure that the GP took responsibility not only for diagnosis and treatment but also for the "promotion of health". ${ }^{38}$ When the Ministry of Health's White Paper on the projected NHS was published in 1944, one reviewer in the Lancet condemned the proposals on the grounds

\footnotetext{
${ }^{32}$ PEP Papers, WG 15/6, memorandum on the preparation of the report on the British health services, [n.d.].

${ }^{33}$ Frances Donaldson, Child of the twenties, London, Rupert Hart Davis, 1959, p. 163.

${ }^{34}$ Halley Stewart Trust Archives, correspondence, note 20 March 1950.

${ }^{35}$ M. R. A. Chance, 'Where from Peckham?', Lancet, 1950, i: 727.

${ }^{36}$ Halley Stewart Trust Archives, correspondence, John Ryle to Williamson, 13 January 1943.

37 John Ryle, Changing disciplines, Oxford University Press, 1948, preface.

38 BMA, op. cit., note 23 above, para. 24.
} 


\section{The Peckham Health Centre}

that they were concerned with medical services rather than with health services. Commenting specifically on the White Paper's proposals regarding the establishment of health centres, the reviewer wrote:

A real Health Service must surely concern itself first with the way people live, with town and country planning, houses and open spaces, with diet, with playgrounds, gymnasia, baths and halls for active recreation, with workshops, kitchens, gardens and camps, with the education of every child in the care and use of his body, with employment and the restoration to the people of the right and opportunity to do satisfying creative work. The true 'health centre' can only be a place where the art of healthy living is taught and practised: it is a most ominous and lamentable misuse of words to apply the name of what is and should be called a 'medical centre'. ${ }^{39}$

A similar theme was taken up in a 'Target for Tomorrow' pamphlet on health published in 1944, which concluded with a call for a "planned campaign for social and positive health" and "health overhauls" for the whole population.40

In the end, it was Williamson and Pearse's inability to compromise that proved their undoing. In the case of the Peckham Health Centre, new trends in social medicine and epidemiology were dismissed because their primary concern was with ways of measuring disease rather than with what they saw as the more fundamental issue of what it was that should be measured; in Williamson's words: "the proof of the pudding is in the eating, not in the statistics of the pudding".41 Williamson and Pearse's refusal to change their research methods made it impossible for the Peckham Centre to obtain grants from the major charitable trusts. Similarly, Williamson's belief in the need for payment of weekly subscriptions made it impossible for the Centre to be absorbed into the NHS. Thus in 1950, the near-bankrupt Centre was sold to the LCC, which continued to operate its recreational facilities under the auspices of an evening educational institute. It is perhaps a final irony that in 1958 the medical direction of the Centre was finally resolved with the opening of a new GP diagnostic centre with $\mathrm{x}$-ray and laboratory facilities and physiotherapy unit in the St Mary's Road building.

\section{ACKNOWLEDGEMENTS}

We are grateful to the Nuffield Foundation for supporting this research.

We would like to thank Brian Abel-Smith (London School of Economics), Celia Davies (University of Warwick), Dan Fox (State University of New York at Stony Brook), and Charles Webster (Oxford University) for their helpful comments on an earlier draft of this paper; and Dr Geof Richman for the transcripts of his 1979 interview with Innes Pearse.

39 'White Paper reviewed. VI. By an urban practitioner', Lancet, 1944, i: 443.

40 J. M. Mackintosh, The nation's health, 'Target for Tomorrow' series, No. 5, London, Pilot Press, 1944, pp. 11-28, 56, 64 .

${ }^{4}$ Halley Stewart Trust Archives, correspondence, Williamson to P. Winfrey, 21 January 1951. 